\title{
The Guarani Aquifer Agreement 2010
}

\section{Francesco Sindico}

Director, Strathclyde Centre for Environmental Law and Governance and

Reader in International Environmental Law, University of Strathclyde Law School, UK

\begin{abstract}
The Guarani Aquifer Agreement, signed in 2010, was the first international treaty to refer in its Preamble to General Assembly Resolution 63/124 on the Law of Transboundary Aquifers. The Agreement includes substantive, procedural and institutional provisions providing Brazil, Argentina, Paraguay and Uruguay with a legal framework for the management of the vast Guarani Aquifer System. This chapter provides an analysis of these provisions, but also discusses socio-legal developments after 2010 and the extent to which the Guarani Aquifer System can be managed by the four countries in the absence of an in-force Guarani Aquifer Agreement.
\end{abstract}

\section{Keywords}

Transboundary aquifer, ILC, Draft Articles, Guarani Aquifer

\section{Contents}

V.29.1 Introduction

V.29.2 The Guarani Aquifer System

V.29.3 The 2010 Guarani Aquifer Agreement

V.29.3.1 Sovereignty as key management principle

V.29.3.2 Sustainable utilization of the GAS

V.29.3.3 Flexibility in the future legal regime for the management of the GAS

V.29.3.4 La Plata River Basin Treaty and the dispute settlement system

V.29.4 Efforts post-2010 in the management of the Guarani Aquifer System

V.29.4.1 Evolving climatic and socio-economic scenario

V.29.4.2 The legacy of the Guarani Project

V.29.4.3 Applicable law in the absence of the Guarani Aquifer Agreement

V.29.5 Conclusions

\section{V.29.1 Introduction}


The Guarani Aquifer Agreement was signed by Argentina, Brazil, Paraguay and Uruguay on 2 August $2010 .{ }^{1}$ It is the first treaty to have been signed regarding the management of a transboundary aquifer system after the adoption of UN General Assembly Resolution 63/124 that annexes the UN International Law Commission (ILC) Draft Articles on the Law of Transboundary Aquifers. ${ }^{2}$ Negotiations between the four Latin American countries sharing the Guarani Aquifer System (GAS) aimed at signing an international agreement moved hand in hand with the work of the UNILC in 2004 and 2005. However, by the end of that year they were interrupted and restarted only in 2010 , when countries were able to reach consensus after only one meeting of formal negotiations. On 2 August in San José Argentina, on the occasion of the meeting of the Heads of State of the MERCOSUR, the four countries solemnly signed the Guarani Aquifer Agreement. After more than four years the Agreement is not yet in force, having been ratified only by Argentina and Uruguay. ${ }^{3}$

This chapter will first provide some necessary background to the hydro-geological and socio-economic characteristics of the GAS. It will then undertake an analysis of the Agreement itself, highlighting its key characteristics, both in terms of normative obligations and institutional framework. Finally, the chapter will briefly touch upon the current status of the management of the GAS, taking into account that the Guarani Aquifer Agreement is not yet in force.

\section{$<$ a $>$ V.29.2 The Guarani Aquifer System}

The GAS is a vast rock strata (geological formations) with aquifer characteristics, forming a vast groundwater reservoir (hydro-geological basin) that stretches over 1,087,879 $\mathrm{Km}^{2}, 71$ per cent of which lies beneath Brazil, 20.98 per cent under Argentina, and 8.05 per cent beneath Paraguay, while 3.32 per cent can be found under the territory of Uruguay. ${ }^{4}$ Brazil can be seen also as the key player when one looks at the population living in the region that lies above the GAS. Of the 15 million people living in the area underlain by the GAS (90

\footnotetext{
* This chapter is up to date as of 1 January 2015.

${ }^{1}$ Acuerdo Sobre el Acuífero Guarani (San Juan, Argentina, 2 August 2010; not yet in force) ('Guarani Aquifer Agreement'). An English version of the Agreement can be found at: http://www.internationalwaterlaw.org/documents/regionaldocs/Guarani_Aquifer_Agreement-English.pdf.

2 The Law of Transboundary Aquifers (UNGA Resolution A/RES/63/124, 11 December 2008).

${ }^{3}$ Uruguay ratified the Guarani Aquifer Agreement on 3 October 2012 and Argentina on 31 October 2012.

${ }^{4}$ Data about the GAS can be found in Organization of American States (2009), in Santa-Cruz (2009) and Foster et al. (2009) 1-12.
} 
million if we include large cities in the proximity of the GAS), an overwhelming majority live in Brazil. Furthermore, 94 per cent of the groundwater exploitation from the GAS takes place in Brazil, with only 3 per cent in Uruguay, 2 per cent in Paraguay and 1 per cent in Argentina.

From a scientific point of view, despite the fact that studies on the GAS had begun prior to the Project for Environmental Protection and Sustainable Development of the Guarani Aquifer System ('the Guarani Project'), ${ }^{5}$ it has been the latter that has allowed the four countries to gain greater insight into its characteristics. Two of the key conclusions that have been reached from a hydro-geological perspective are the following. Firstly, the water is renewable, but circulation is slow. Recharge zones lie principally in the outcrop regions, some of which can be found along the borders of a number of the countries sharing the GAS. ${ }^{6}$ Secondly, the water quality is very good and it is therefore a perfect source for the drinking needs of the population living on top of the GAS, where water can be reached. Problems of contamination and over-exploitation do not seem to be present to a significant extent for the time being, but change in land uses could threaten the overall quality of the GAS water. ${ }^{7}$

While some studies stress the exceptional volumes of water present in the GAS, suggesting that it could provide enough drinking water for a population of 5.5 billion people for the next 200 years, the truth is that it is very difficult to say precisely how much water is contained within the GAS. ${ }^{8}$ What the Guarani Project has highlighted is that water security in the region is guaranteed by the GAS, indicating that its sustainable management is paramount in the long term. ${ }^{9}$ While a treaty is not a condition sine qua non for the sustainable management of any transboundary aquifer, it does demonstrate an increased spirit of cooperation between States sharing the natural resource. The Guarani Aquifer Agreement can be seen through these lenses. It will not be the panacea for the solution of all possible

\footnotetext{
${ }^{5}$ The Environmental Protection and Sustainable Development of the Guarani Aquifer System Project (the Guarani Project) was a six-year project (2003-2009) that involved cooperation between the four countries and a number of international agencies (the Global Environment Facility, the World Bank, the Organization of American States, the Dutch and German Governments and the International Atomic Energy Agency. On the Guarani Project see, amongst others, Green (2010a) 369-379; Amore and Tröger (2010); and Giraut et al. (2010).

${ }^{6}$ Organization of American States (2009).

7 ibid.

8 ibid.

9 ibid.
} 
problems regarding the management of the GAS, but it does show an increased political will to cooperate in the management and regulation of the GAS.

\section{$<$ a $>$ V.29.3 The 2010 Guarani Aquifer Agreement}

As mentioned in the introduction, Argentina, Brazil, Paraguay and Uruguay had already started negotiating an international legal instrument over the management of the GAS in 2004. ${ }^{10}$ At the same time as comments were being made by government representatives before the UNILC during its work on the international law of transboundary aquifers, representatives from the four countries were also negotiating a possible treaty for the management of the GAS. Negotiations were interrupted in 2005, a period when tensions between Argentina and Uruguay over the construction of a pulp mill on the Uruguayan shores of the River Uruguay ran high. At the same time, however, the two countries (and Brazil and Paraguay) were collaborating in the framework of the Guarani Project, which culminated in 2009 with a set of policy recommendations as to the way forward in the management of the GAS. ${ }^{11}$ Finally, in 2010 the four countries reconvened negotiations and agreed very swiftly on the text of the Guarani Aquifer Agreement. Whether a coincidence or not is not for this chapter to speculate, ${ }^{12}$ but by the date of the signature of the Agreement the Pulp Mills case was (at least formally) over before the International Court of Justice, ${ }^{13}$ the Guarani Project had ended and the UNILC Draft Articles had been adopted by UN General Assembly 63/124.

The Guarani Aquifer Agreement provides a broad legal framework within which Argentina, Brazil, Paraguay and Uruguay are required to manage the GAS. ${ }^{14}$ The preamble of the Agreement refers to a number of previous international documents that the countries have taken into account in the negotiation process. Amongst other issues, the Guarani Aquifer Agreement mentions specifically that it is '[T] aking into account the Resolution 63/124 of the United Nations General Assembly on the Law of Transboundary Aquifers', thereby formally

\footnotetext{
${ }^{10}$ This chapter does not discuss the earlier efforts to map and manage the GAS. These are discussed in Taks (2009) 9-13. It also does not expand on the efforts undertaken at MERCOSUR level prior to the adoption of the Guarani Aquifer Agreement to manage the GAS. Information about these efforts can be found in Villar and Ribeiro (2011) 650-652.

${ }^{11}$ Organization of American States (2009).

12 Sindico (2011).

${ }^{13}$ ICJ 20 April 2010, Pulp Mills on the River Uruguay (Argentina v Uruguay), [2010] ICJ Rep. 14

${ }^{14}$ On the Guarani Aquifer Agreement see Cassuto and Sampaio (2011); Cassuto and Sampaio (2013)' RubioFernández (2009); Sindico (2011); Villar and Ribeiro (2011); and del Castillo-Laborde (2012).
} 
acknowledging the work done by the UNILC that has led to the adoption of the Draft Articles on the Law of Transboundary Aquifers. The Guarani Aquifer Agreement also mentions the results arising from the Guarani Project and describes them as 'valuable'. ${ }^{15}$

The analysis of the Guarani Aquifer Agreement leads to the following observations: $<\mathrm{nl}>$

(1) Sovereignty can be considered a key management principle, but only in the context of applicable international law.

(2) Within the context of the obligation not to cause significant harm, Parties are allowed, if not encouraged, to sustainably use the GAS.

(3) There is a common acknowledgement of the need to advance scientific knowledge on the GAS and to identify critical areas, both of which require built-in flexibility in the future legal regime for the management of the GAS.

(4) The future institutionalization of the Guarani Aquifer Agreement lies in the La Plata River Basin Treaty, which will also play a role in the dispute settlement mechanism of the Guarani Aquifer Agreement. However, the latter will need to be completed by a Protocol on the arbitration procedure to be used in the case that a dispute is not solved by other means. $</$ list $>$

\section{$<b>V .29 .3 .1$ Sovereignty as key management principle}

Articles 1 to 4 of the Guarani Aquifer Agreement set the foundations of the management of the GAS. ${ }^{16}$ Articles 1 and 2 seem to place a strong emphasis on 'sovereignty' by maintaining that Argentina, Brazil, Paraguay and Uruguay 'are the sole owners of this resource' and that 'each Party exercises territorial sovereignty over their respective shares of the Guarani Aquifer System'.

However, this emphasis on national sovereignty is counterbalanced by the fact that reliance thereon must be framed in the context of 'applicable international law'. ${ }^{17}$ Article 3

\footnotetext{
${ }^{15}$ Guarani Aquifer Agreement, supra (n 1), Preamble.

${ }^{16}$ The definitions of aquifer in the UNILC Draft Articles, supra note 2, and in the 2010 Guarani Aquifer Agreement differ. According to Draft Article 2(a), an aquifer is 'a permeable water bearing geological formation underlain by a less permeable layer and the water contained in the saturated zone of the formation'. On the contrary, the Guarani Aquifer Agreement puts emphasis solely on the water resources of an aquifer by maintaining in its Article 1 that 'The Guarani Aquifer System is a transboundary water resource....' (emphasis added). This difference has been noted by Navarro Lins Brzezinski (2010) 3-4.

${ }^{17}$ Guarani Aquifer Agreement, supra (n 1), Article 2.
} 
clarifies that in the management of the GAS the Parties must respect 'the obligation not to cause significant harm', which is further expanded in Articles 5 and 7 where it is clarified that, if significant harm nevertheless occurs, the Party responsible 'shall adopt all appropriate measures to eliminate or mitigate such harm'. Article 4 of the Guarani Aquifer Agreement explains that the management of the GAS is aimed to achieve the reasonable and equitable use of its water resources. The latter provision can be interpreted as the application of the principle of equitable and reasonable utilization.

In sum, while sovereignty does seem to be the cornerstone principle of the Guarani Aquifer Agreement, a closer look at the text demonstrates that it is tempered by the application of the obligation not to cause significant harm and of the principle of equitable and reasonable utilization. ${ }^{18}$

\section{$<b>V .29 .3 .2$ Sustainable utilization of the GAS}

Article 8 of the Guarani Aquifer Agreement requires Parties to exchange information regarding activities that they may be considering undertaking on the GAS. This provision, as well as the following ones that further clarify the nature of this obligation, fall along the lines of UNILC Draft Article 8 titled 'Regular exchange of data and information'.

Articles 9 and 10 reiterate this obligation and mention that a Party, where it fears that an activity undertaken by another one may lead to significant harm within its territory, can request the results arising from an environmental impact assessment. ${ }^{19}$ Article 11 determines the procedure in the case of a dispute between a country wishing to undertake an activity on

\footnotetext{
${ }^{18}$ Some authors do not agree with such a positon, and consider that the reference to national sovereignty cannot be counterbalanced by general references to applicable international law. See McCaffrey (2009) and McIntyre (2011). Others, like del Castillo-Laborde (2010) 3, see references to sovereignty in the Draft Articles as a means to prevent groundwater being considered akin to the deep sea bed by granting it a common heritage of mankind legal status. Cassuto and Sampaio (2011) 665 take a further approach, suggesting that 'This debate over the extent and understanding of what sovereignty means is unlikely to be resolved any time soon. In the interim, a more practical solution would be to recognize that states can and must collaborate based on a shared vision of existing principles of domestic and international environmental laws'.

${ }^{19}$ Public participation is not mentioned explicitly in the Guarani Aquifer Agreement. However, if public participation is to be considered an inherent part of an environmental impact assessment process, then public participation should feature prominently in the management of the GAS; see on this point Etemire and Sindico (2015). Cassuto and Sampaio (2013) 32-33 also highlight the importance of public participation as a management principle for the GAS.
} 
the GAS and another country claiming that it may lead to a significant harm in its territory. If there is 'prima facie evidence that the proposed activities or work may cause significant harm in its territory or environment', the State carrying out such an activity is required to stop. Before reinitiating any activity it must wait for the outcome of the negotiations and consultations, which must be carried out in good faith between the two Parties and cannot last more than six months.

In sum, the Guarani Aquifer Agreement does place a lot of emphasis on the obligation not to cause significant harm, but not to the extent of stopping any activity on the GAS. ${ }^{20}$

\section{$<b>V .29 .3 .3$ Flexibility in the future legal regime for the management of the GAS}

The Preamble clearly affirms the need to advance scientific understanding of the GAS by stating that the Parties are "motivated by the desire to expand the levels of cooperation with regard to a greater scientific understanding on the Guarani Aquifer System'. The preambular language of an agreement represents the context that can be used to interpret the treaty, but it does not lay out binding obligations. ${ }^{21}$ Therefore, one has to see whether this plea for further scientific knowledge can be found elsewhere in the Guarani Aquifer Agreement.

Article 12 reads as follows:

$<$ quotation $>[\mathrm{T}]$ he Parties shall establish cooperation programs with the purpose of extending the technical and scientific knowledge on the Guarani Aquifer System, promoting the exchange of information and management practices, and developing joint projects. $</$ quotation $>$

By using the verb 'shall' the Parties have established a strong legal obligation aimed at advancing scientific knowledge on the GAS. This leads to an observation, which characterizes many environmental treaties. ${ }^{22}$ The Guarani Aquifer Agreement can be seen as

\footnotetext{
${ }^{20}$ Green (2010a) 385-386 argued that a future Agreement (he was writing prior to the 2010 Guarani Aquifer Agreement) could well do without equitable utilization, but should just focus on sustainable and reasonable utilization. He defended this on the basis of the vast amounts of groundwater reserves. The 2010 Guarani Aquifer Agreement finally settled for 'equitable and reasonable' in Article 4. However, equitable is not present in Article 3.

${ }^{21}$ Preamble and Vienna Convention on the Law of Treaties (VCLT).

${ }^{22}$ This is, indeed, the case for most framework treaties, such as the United Nations Framework Convention on Climate Change (adopted 9 May 1992, entered into force 21 March 1994) (1992), 31 ILM 822 or the Convention on Biological Diversity, Rio de Janeiro, 5 June 1992, entered into force on 29 December 1993, 31 ILM (1992), at 818.
} 
a starting point, and not as the ultimate legislative framework for the sustainable management of the GAS. Should scientific understanding on the transboundary aquifer system evolve, this may lead the Parties to reconsider some parts of the Guarani Aquifer Agreement itself to make it more responsive to the new findings.

Likewise, Article 14 of the Guarani Aquifer Agreement lends itself to a similar observation. The provision maintains that 'the Parties shall cooperate in the identification of critical areas, especially boundary areas that require specific treatment measurements'. The Guarani Project had identified four pilot projects, two of which were transboundary: Santana do Livramento/Rivera (Brazil/Uruguay) and Concordia/Salto (Argentina/Uruguay). The Guarani Aquifer Agreement encourages identifying critical areas with particular attention on boundary regions in order to consider whether or not to adopt 'specific measures'. It is too soon to speculate on the nature of these specific measures, ${ }^{23}$ but these could be a very useful instrument to sustainably manage a transboundary aquifer system as vast and diverse as the GAS. It is, once again, similar to what we have mentioned in reference to the advancement of scientific knowledge; an acknowledgement of the necessary degree of flexibility that the Guarani Aquifer Agreement needs to have in order to accommodate new or different situations.

\section{V.29.3.4 La Plata River Basin Treaty and the dispute settlement system}

The Strategic Action Programme of the Guarani Aquifer Project provided the countries sharing the GAS with a number of recommendations regarding the possible future institutional setting of the management of the GAS. ${ }^{24}$ Options 4 and 5 mentioned the La Plata River Basin Treaty as a possible institutional forum in which to take forward the management of the GAS. Article 15 of the Guarani Aquifer Agreement provides a stamp of approval to this option by maintaining that a 'Commission' will be established within the framework of the La Plata River Basin Treaty ${ }^{25}$ 'in order to coordinate the cooperation between the Parties for the compliance of the principles and objectives of this Agreement'.

\footnotetext{
${ }^{23}$ Villar and Ribeiro (2011) 654-655 take a slightly less positive view of this provision, since according to these authors: 'the focus of Article 14 seems to be to identify areas that require measures to restrict or control rather than the design of a policy based on precaution and prevention'.

${ }^{24}$ Organization of American States (2009).

${ }^{25}$ El Tratado de la Cuenca de la Plata, Brasilia, 23 April 1969, entered into force on 14 August 1970, available at http://www.cicplata.org/?id=tratado. For further information on this treaty see Pochat (2011).
} 
The Commission will play an important role in the future dispute settlement mechanism of the Guarani Aquifer Agreement. According to Article 16, should a dispute arise over the interpretation or the application of the Agreement, the Parties will firstly try to solve the controversy through direct negotiations, the results of which must be notified to the Commission. Should negotiations fail, the Commission takes up a quasi-judicial function by having the possibility of formulating recommendations regarding the dispute after having received the divergent positions from the Parties in conflict. Two important caveats must be made: a dispute can reach the Commission only by 'mutual agreement ${ }^{26}$ and recommendations must be given no more than 60 days after the intervention of the Commission has been requested. If a dispute is not solved by direct negotiations (Article 16) or through the involvement of the Commission (Articles 17 and 18), then the Parties will refer to the arbitration procedure stipulated in Article $19 .{ }^{27}$ One of the reasons why negotiations between the four countries were interrupted in 2005 was because of disagreement on how to trigger the dispute settlement system that was being discussed. In 2010 the countries seem to have decided to leave the issue of arbitration to a second stage of negotiations and move ahead in the consensus of the general framework.

This means that the two items on the agenda of the negotiations following the signature of the Guarani Aquifer Agreement, and parallel to the ratification thereof, are: the creation of the Commission under the La Plata River Basin Treaty and the negotiation of a Protocol on arbitration procedure. Neither will be easy tasks. The creation of the Commission will have budgetary implications and the relationship with the La Plata River Basin Treaty institutional setting itself will need to be addressed. The negotiation towards a Protocol on arbitration procedure will require the four countries to decide whether to resume matters from where they left them in 2005 , or devise a new mechanism capable of successfully compromising between the different positions.

The final provisions of the Guarani Aquifer Agreement are only operative. Article 20 clarifies that no reservations will be admitted, while Article 21 includes rules on the entry into force, duration (unlimited) and on the depositary (Brazil), and Article 22 on the possibility of denouncing the Agreement.

\footnotetext{
${ }^{26}$ Guarani Aquifer Agreement, supra (n 1), Article 17.

${ }^{27}$ The dispute settlement system as laid out in the Guarani Aquifer Agreement is deemed insufficient by Cassuto and Sampaio (2013) 36-40 who suggest that disputes should be referred to the International Court of Justice.
} 


\section{$<a>V .29 .4$ Efforts post-2010 in the management of the Guarani Aquifer System}

The euphoria following the adoption of the Guarani Aquifer Agreement within the transboundary aquifer community soon turned into concern regarding the prospect of having an Agreement, but it not entering into force. Those who had hoped for a swift ratification on behalf of the four countries were soon to be proved wrong, with countries taking their time in undertaking the necessary domestic legislative steps for ratification of the Guarani Aquifer Agreement. Concern turned into frustration since only Argentina and Uruguay have (as of February 2015) ratified the Agreement, with Brazil and Paraguay lagging behind. With no immediate prospect of these two countries ratifying the Guarani Aquifer Agreement, the question of what has been done (if anything at all) in the management of the GAS in the absence of an international treaty becomes pertinent. This last section will briefly discuss the evolving climatic and socio-economic scenario facing the GAS, the legacy of the Guarani Project in terms of management of the GAS and the applicable law in the absence of the Guarani Aquifer Agreement.

\section{$<b>$ V.29.4.1 Evolving climatic and socio-economic scenario}

One would think that in four years the scientific understanding of the GAS would not change significantly. The reality is that some of the challenges that the region had been predicted to face in the Guarani Project are appearing much sooner than expected. This is the case, particularly, for climate change. ${ }^{28}$ And, more precisely, climate change effects in some of the Brazilian sides of the aquifer. The State of São Paulo is currently facing the most severe drought of the last eighty years. ${ }^{29}$ This is, inevitably, putting more pressure on its water resources, with potential implications for the GAS. In fact, projects are already being considered that would further tap into the groundwater resources present in the GAS as a way to minimize the effects of this (and future) droughts in the São Paulo region. In the long term, together with further use of groundwater for the increasing agro business in the area, increased reliance on the GAS for water uses could impact on the available quantity of water.

\footnotetext{
${ }^{28}$ Organization of American States (2009).

${ }^{29}$ See The Guardian (24 March 2014), 'Desperately Seeking Solutions to Worst Drought in Decades in Brazil', available at http://www.theguardian.com/global-development-professionals-network/2014/mar/24/brazildesperate-for-drought-solutions.
} 
Considering the vast amount of groundwater present in the GAS, ${ }^{30}$ this is not too concerning, and the Guarani Aquifer Agreement itself favours using the resources trapped in the GAS, albeit in a sustainable manner. ${ }^{31}$ What is problematic is that, without an ad-hoc well-functioning intergovernmental body tasked to continuously monitor the quantity and quality of groundwater reserves in the GAS, the possibilities to manage the aquifer sustainability decline substantially. It may be redundant, but it is very difficult to manage what you do not know. The Guarani Project had initiated exchange of information and sharing of data between the four countries. Provisions of the Guarani Aquifer Agreement maintained level of exchange as one of the key obligations for the GAS countries. ${ }^{32}$ Without the Guarani Project and with the Guarani Aquifer Agreement not in force, the sustainability of the GAS is at risk, especially taking into account how climate change and socio-economic pressures are impacting the region.

\section{$<b>$ V.29.4.2 The legacy of the Guarani Project}

Can there be any management without the Guarani Aquifer Agreement entering into force? Fortunately, some countries have not completely forgotten the GAS and have taken steps to continue, where possible, some of the good practices developed in the Guarani Project, especially in the fields of data collecting and bilateral groundwater management projects.

In terms of data collection, programmes are currently present in only two countries. In Brazil, the Brazilian Geological Survey launched RIMAS (Groundwater Integrated Monitoring Network), which is monitoring the GAS unconfined areas through 40 wells and 13 meteorological stations. ${ }^{33}$ The Argentinian government created a national monitoring network, which includes one major water quality sampling campaign. ${ }^{34}$ In 2014, the Brazilian National Water Agency (ANA) finalized a project aimed at mapping, and promoting a better

\footnotetext{
${ }^{30}$ See supra (n 8).

${ }^{31}$ See Guarani Aquifer Agreement, art 4.

32 ibid, art 8.

${ }^{33}$ Information about RIMAS is available at http://www.cprm.gov.br/publique/media/folder_final_RIMAS.pdf.

${ }^{34}$ In parallel, the city of Ribeirão Preto has its own network for monitoring the quality ( 8 wells) and hydraulic head ( 8 wells) of the GAS, with measurements taken every 15 days and annual chemical analysis. This network is a requirement of the Pardo River Basin Committee (http://www.ciiagro.org.br/).
} 
understanding of the vulnerability of, the whole outcrop area of the GAS in the country. ${ }^{35}$ At the same time, several studies in the four countries have focused on different aspects of GAS. $^{36}$

At a regional level the Regional Centre for Groundwater Management for Latin America and the Caribbean (CeReGAS) was established in Montevideo in November 2013, under the responsibility of the UNESCO Regional Science Office for Latin America and the Caribbean. Management actions based on the work of the Guarani Project were suggested as one of its priorities. ${ }^{37}$

Tangible projects aimed at developing groundwater management plans that include two countries within the GAS with the participation of local stakeholders was one of the highlights of the Guarani Project. ${ }^{38}$ Interestingly this good practice arising from the previous management of the GAS has not been lost completely. In fact, there are still several bilateral initiatives, such as those in Santana do Livramento (Brazil) and Rivera (Uruguay). Here an agreement between the UDELAR (Universidad de la República del Uruguay) and CPRM SUREG-RS (Brazilian Geological Survey) is implementing a new numerical model, which will assist in the management of GAS water management at city level. A second project can be found in Artigas (Uruguay) and Quaraí (Brazil), where the CPRM and the local water supply companies CORSAN (Rio Grande do Sul) and OSE (Uruguay) are finalizing a project to assist the management of GAS. Further bilateral projects can be found between Concordia and Salto and between Pedro Juan Caballero (Paraguay) and Ponta Porã (Mato Grosso do

\footnotetext{
35 This regional scale project, Estudo de Vulnerabilidade Natural à Contaminação e Estratégias de Proteção do Sistema Aquífero Guarani nas Áreas de Afloramento, was complementary to the one previously developed by IPT (Institute for Technological Research) in the state of São Paulo.

${ }^{36}$ In Brazil one can highlight the UNESP (Rio Claro) project, which includes hydro-geochemical and isotope studies and management, the USP-EESC (São Carlos), which evaluates GAS recharge with different land uses and aquifer numerical modelling, and the CEPAS/USP-SP focusing on water resource development and management.

${ }^{37}$ See the 20 March 2014 UNESCO press release at http://www.unesco.org/new/en/media-services/singleview/news/unesco_and_uruguay_establish_a_regional_centre_for_groundwater_management_for_latin_americ a_and_the_caribbean/back/9597/\#.VONsaeasX4s.

${ }^{38}$ Organization of American States (2009).
} 
Sul, Brazil). Two of these projects are running as follow ups to the pilot projects that had been established in the framework of the Guarani project. ${ }^{39}$

\section{$<b>V .29 .4 .3$ Applicable law in the absence of the Guarani Aquifer Agreement}

Considering the above-mentioned changing climatic conditions, what policy options are available in addition to the options developed nationally and bilaterally? This is relevant should any planned activity be likely to have a transboundary impact. Take for example the planned drought relief plans currently being considered in Brazil. There are talks of a new well field producing $1 \mathrm{~m}^{3} / \mathrm{s}$, which would serve the cities of the Piracicaba-Campinas region, as a strategy to alleviate the water crisis in the Metropolitan Region of São Paulo. ${ }^{40}$ If a project of this magnitude were to be carried out closer to a border region, this may have water quantity transboundary impacts.

An in-force Guarani Aquifer Agreement would have, hypothetically, a Commission that would be informed of such a plan and would coordinate and manage any action that was required in order to consider and, if necessary, mitigate any transboundary impact, especially if it were to amount to significant harm. ${ }^{41}$ But, for the time being, this is not the case. Hence, countries would necessarily draw on general rules applicable to the management of transboundary aquifers. These can be found in the UNILC Draft Articles on the Law of Transboundary Aquifers. ${ }^{42}$ In the latest debates at the UN General Assembly these should now guide, and not just be taken into account by, States wishing to devise agreements to manage transboundary aquifers. ${ }^{43}$ We have already seen that the Guarani Aquifer Agreement is the first agreement worldwide to make explicit reference to the Draft Articles. ${ }^{44}$ One can argue that these have both partly inspired the Agreement and have also contributed to its adoption. The question is whether they can fill the gap until the Guarani Aquifer Agreement enters into force. They definitely can in terms of general principles and obligations, but much

\footnotetext{
${ }^{39}$ The author wishes to thank Ricardo Hirata for sharing information about the projects referred to in section 4.2 and for the recent developments mentioned in section 4.1 of this chapter.

${ }^{40}$ A study carried out by the University of São Paulo estimated a cost of US\$140 million to construct 24 wells (250 $\mathrm{m}$ depth) and a $30 \mathrm{~km}$ pipeline.

${ }^{41}$ See supra V.29.3.4.

${ }^{42}$ See supra (n 2).

${ }^{43}$ The Law of Transboundary Aquifers (UNGA Resolution A/RES/66/104, 13 January 2012), at paragraph 1, and Eckstein and Sindico (2014).

44 See Guarani Aquifer Agreement, preamble.
} 
less so in terms of institutional support. The Guarani Aquifer Agreement shares similar, if not identical, principles with the Draft Articles. In addition, general international law (customary international law) will apply. However, without an established and well-resourced intergovernmental Commission there are limits to how much States can rely on principles and customary international law.

\section{V.29.5 Conclusions}

So, why is the Guarani Aquifer Agreement not yet in force; and what could be done to speed up its entry into force. It is self-evident that the problem is of a political nature. Put simply, until all four GAS countries ratify the Guarani Aquifer Agreement it will not enter into force. ${ }^{45}$ Paraguay may adduce political tensions with its neighbours as a reason for not ratifying, ${ }^{46}$ while one can speculate that for Brazil the management of the GAS (or at least its transboundary management) has not been a priority since 2010 . How to incentivize the governments of Paraguay and Brazil to ratify the Guarani Aquifer Agreement is again a delicate and political question. However, what can be done is to showcase to the four countries how much interest there has been worldwide (at least in the transboundary aquifer community) in the Guarani Aquifer Agreement. ${ }^{47}$ What may not seem a priority domestically, has been hailed now for several years as a milestone in transboundary aquifer management.

Whatever one may think about the Guarani Aquifer Agreement, the very fact that four countries have sat around a table and agreed a common set of management principles before any particular water crisis has occurred can be considered per se as a good practice. ${ }^{48}$ It would be a pity not to give such good practice a chance to deliver just because of the lack of political will in two of the four GAS countries.

\section{$<$ a $>$ Bibliography}

\footnotetext{
${ }^{45}$ In 2011 the São Paulo Statement on the Management of the GAS called the four States to follow up the ratification process; see the Statement at http://www.igme.es/boletin/2012/123_3.htm.

${ }^{46}$ Dettoni (2013).

${ }^{47}$ In December the transboundary aquifer community gathered in Paris at the 2010 UNESCO ISARM

Conference. The Guarani Aquifer Agreement featured prominently in the programme just a few months after its adoption.

48 This point is shared by Villar and Ribeiro (2011) 646: 'The most significant point of this Agreement is the absence of conflicts over the use of the Guarani Aquifer prior to the preparation of this document despite its spatial extent, water volume and strategic importance'.
} 
Amore L and Tröger U, Transboundary Guarani Aquifer System and Groundwater Management Mechanisms. ISARM2010 International Conference. Transboundary Aquifers: Challenges and New Directions, 6-8 December 2010. UNESCO-IHP, ISARM and PCCP (UNESCO, Paris 2010).

Cassuto D and Sampaio RR, 'Keeping it Legal: Transboundary Management Challenges Facing Brazil and the Guarani.' (2011) 36(5) Water International 661.

Cassuto DN and Sampaio R 'Hard, Soft \& Uncertain: The Guarani Aquifer and the Challenges of Transboundary Groundwater' (2013) 24(1) Colorado Journal of International Environmental Law and Policy 1.

del Castillo-Laborde L, The Law of Transboundary Aquifers and the Berlin Rules on Water Resources (ILA): Interpretive Complementarity. ISARM2010 International Conference. Transboundary Aquifers: Challenges and New Directions, 6-8 December 2010. UNESCO-IHP, ISARM and PCCP. (UNESCO, Paris 2010).

del Castillo-Laborde L, 'The Guaraní Aquifer Framework Agreement' in L Boisson de Chazournes, C Leb and M Tignino (eds), International Law and Freshwater: The Multiple Challenges (Edward Elgar 2012).

Dettoni J, 'Proyecciones 2013: Es hora de que Brasil y Paraguay ratifiquen el acuerdo sobre el acuífero Guaraní', BN Americas, 4 January 2013, available at http://www.bnamericas.com/features/aguasyresiduos/proyecciones-2013-es-hora-deque-brasil-y-paraguay-ratifiquen-el-acuerdo-sobre-el-acuifero-guarani.

Eckstein G and Sindico F, 'The Law of Transboundary Aquifers: Many Ways of Going Forward, but Only One Way of Standing Still' (2014) 23(1) Review of European, Comparative and International Environmental Law 32.

Etemire U and Sindico F, 'Public Participation and the Guarani Aquifer Agreement' in M Tignino and K Sangbana (eds), Public Participation and Water Resources Management: Where do We Stand in International Law? International Conference Proceedings, Geneva, 13 December 2013 (UNESCO 2015) 55-61.

Foster S and Hirata R et al., The Guarani Aquifer Initiative - Towards Realistic Groundwater Management in a Transboundary Context. GW•MATE Case Profile Collection Number 9 (World Bank, Washington DC 2009).

Giraut MA and Laboranti C et al., Guarani Aquifer System Project: Strengths and Weaknesses of its Implementation. ISARM2010 International Conference. Transboundary Aquifers: Challenges and New Directions, 6-8 December 2010. UNESCO-IHP, ISARM and PCCP (UNESCO, Paris 2010). 
Green BA, 'The Guarani Aquifer and International Groundwater Law: Advancing Towards a Legal Framework for the Management of a Transboundary Aquifer' (2010a) 13 University of Denver Water Law Review 361.

Green B, 'Contemporary Governance of Transboundary Groundwater Resources: The Guarani Aquifer Project' (2010b) 21(6) The Journal of Water Law 232.

Kemper KE, Mestre E and Amore L, 'Management of the Guarani Aquifer System: Moving Towards the Future' (2009) 28(2) Water International 185.

McCaffrey S 'The International Law Commission Adopts Draft Articles on Transboundary Aquifers' (2009) 103 American Journal of International Law 272.

McIntyre O, 'International Water Resources Law and the International Law Commission Draft Articles on Transboundary Aquifers: A Missed Opportunity for CrossFertilisation?' (2011) 13 International Community Law Review 237.

Navarro Lins Brzezinski ML, Regulating Transboundary Groundwater: Big Challenges for Brazil. ISARM2010 International Conference. Transboundary Aquifers: Challenges and New Directions, 6-8 December 2010. UNESCO-IHP, ISARM and PCCP (UNESCO, Paris, 2010)

Organization of American States, Guarani Aquifer: Strategic Action Program, Report on the Project for Environmental Protection and Sustainable Development of the Guarani Aquifer System (2009), available at http://iwlearn.net/iwprojects/974/reports/strategic-action-program/view.

Pochat V, 'International Agreements, Institutions and Projects in La Plata River Basin' (2011) 27(3) International Journal of Water Resources Development 497.

Rubio-Fernández EM, 'La gestión integrada de los recursos hídricos: breve referencia al acuífero guaraní' in C Gutiérrez-Espada, R Riquelme-Cortado, E Orihuela-Calatayud et al., El agua como factor de cooperación y de conflicto en las relaciones internacionales contemporáneas. (Murcia, Instituto Euromediterráneo del Agua, 2009) 217-226.

Santa-Cruz JN, ‘Sistema Acuífero Guaraní: El conocimiento hidrogeológico’ (2009) 19(112) Ciencia Hoy 8.

Sindico F, 'The Guarani Aquifer System and the Law on Transboundary Aquifers' (2011) 13 International Community Law Review 255.

Taks J, El Acuifero Guaraní en debate (Editorial Cotidiano Mujer 2009), available at http://www.laredvida.org/im/bolentines/acuifero_guarani09.pdf. 
Villar PC and Ribeiro WC, 'The Agreement on the Guarani Aquifer: A New Paradigm for Transboundary Groundwater Management?' (2011) 36(5) Water International 646. 